\title{
ANALISIS LAPORAN KEUANGAN BERDASARKAN TINGKAT RENTABILITAS PADA PT. BANK PERKREDITAN RAKYAT (BPR) BATANG KAPAS
}

\author{
${ }^{1)}$ Rahmatil Fauziah, ${ }^{2}$ Afriyeni \\ ${ }^{1,2)}$ Akademi Keuangan dan Perbankan Padang \\ rahmatilfauziah16@gmail.com
}

\begin{abstract}
The purpose of this study was to determine the level of profitability by using the ratio of ROA (Return On Assets), ROE (Return On Equity), and NPM (Net Profit Margin) at PT. BPR Batang Kapas. The type of data used is secondary data, data is collected by going directly to the object of research to obtain financial statement data and other data needed during the 2015-2019 period. Based on the profitability analysis, it can be seen that ROA is in a healthy condition and ROE is also in a healthy condition, and NPM is also in a healthy condition in obtaining net profit. The results showed that the level of bank profitability is good and efficient in running the company's operations.
\end{abstract}

Keywords: profitability, Rular Bank, ROA, ROE, NPM.

\section{PENDAHULUAN}

Pada era ini peranan perbankan sangatlah penting bagi masyarakat di Indonesia, pada dasarnya perbankan bertujuan untuk menunjang pembangunan nasional dalam meningkatkan kesejahteraan rakyat. Perbankan merupakan suatu lembaga berperan sebagai perantara keuangan antara pihak kelebihan dengan kekurangan dana, agar lebih meningkatkan taraf hidup ekonomi masyarakat. Dalam hal ini peranan perbankan sangatlah penting dalam perekonomian sebagai pelajuan sektor ekonomi di Indonesia.

Menurut Undang-Undang RI Nomor 10 Tahun 1998 Tentang Perubahan Undang-Undang Nomor 7 Tahun (1992) bank ialah badan usaha menghimpun dana dari masyarakat dalam bentuk simpanan dan menyalurkannya kembali pada bentuk kredit atau bentuk-bentuk lainnya dalam rangka meningkatlkan taraf hidup rakyat banyak.

BPR tumbuh dan berkembang di masyarakat berpengaruh dalam memacu pertumbuhan ekonomi khususnya usaha kecil. Kondisi ini wajar karena BPR memang lahir dari masyarakat bawah, sehingga BPR tetap menyatudengan masyarakat. Keberadaan BPR di Indonesia mampu menunjukkan perannya memberikan jasa pelayanan kepada usaha kecil. Agar dapat melaksanakan tugas pokok dan mempertahankan kelangsungan BPR, kepercayaan masyarakat sangat penting.

Menurut Fernos (2017) dan Mirza \& Afriyeni (2019) laporan keuangan adalah laporan yang berisikan bagian dari pelaporan keuangan. Diantaranya 
meliputi neraca, laporan laba rugi, posisi keuangan yang disajikan dengan berbagai tata cara, contohnya sebagai laporan arus kas ataupun arus dana.

Menurut Harahap (1997) dan Afriyeni \& Putri (2019) analisis laporan keuangan adalah menguraikan pos-pos laporan keuangan menjadi unit informasi yang lebih kecil dan melihat hubungan bersifat signifikan antara data kuantitatif ataupun non-kuantitatif. Analisis laporan keuangan melibatkan penggunaan berbagai macam laporan keuangan yang terdiri atas bagian tertentu mengenai suatu informasi yang penting (Fernos \& Dona, 2018).

Dalam menilai kinerja keuangan bank dilakukan mereview data laporan keuangan, menghitung, membandingkan atau mengukur, serta menginterpretasikannya. Perhitungan dilakukan untuk menganalisis kinerja keuangan pada bank bisa menggunakan berbagai teknik analisis, diantaranya yaitu analisis rasio.

Saat menganalisa serta menilai posisi keuangan suatu perusahaan mempunyai tujuan akhir yang ingin dicapai oleh suatu perusahaan terpenting yaitu memperoleh laba atau praktiknya dituntut mampu memenuhi target yang telah ditetapkan artinya besar keuntungan haruslah dicapai sesuai diharapkan bukan berarti asal untung. Untuk mengukur tingkat keuntungan suatu perusahaan, digunakan rasio rentabilitas.

Penggunaan rentabilitas bagi bank maupun pihak luar berguna menghitung laba dari waktu ke waktu, serta mengukur produktifitas dari keseluruhan dana dipergunakan baik modal pinjaman ataupun modal sendiri. Rasio rentabilitas yaitu rasio digunakan menghitung profit diperoleh dari modal-modal yang digunakan operasi tersebut atau mengukur kemampuan perusahaan untuk memperoleh keuntungan (Munawir, 2004). Rasio rentabilitas bisa dihitung menggunakan, Return on Assets (ROA), Return on Equity (ROE), Net Profit Margin (NPM).

PT. BPR Batang Kapas adalah salah satu BPR yang terdapat di Sumatera Barat. BPR ini harus memperhatikan tingkat rentabilitas yang dimilikinya agar dapat mencapai suatu keuntungan yang lebih dimasa mendatang. Untuk mengetahui bagaimana kemampuan PT. BPR Batang kapas dalam menggunakan modalnya secara efisien dalam menghasilkan laba selama periode tertentu. Berikut perkembangan ROA, ROE, NPM PT. BPR Batang Kapas.

\section{Tabel 1}

Perkembangan Rasio Rentabilitas PT. Bank Perkreditan Rakyat Batang Kapas Tahun 2015-2019

\begin{tabular}{cccccc}
\hline Keterangan & \multicolumn{5}{c}{ Tahun } \\
\cline { 2 - 6 } & $\mathbf{2 0 1 5}$ & $\mathbf{2 0 1 6}$ & $\mathbf{2 0 1 7}$ & $\mathbf{2 0 1 8}$ & $\mathbf{2 0 1 9}$ \\
\hline ROA & $2,24 \%$ & $2,07 \%$ & $2,14 \%$ & $2,04 \%$ & $2,07 \%$ \\
ROE & $19,37 \%$ & $14,21 \%$ & $16,26 \%$ & $14,10 \%$ & $12,53 \%$ \\
NPM & $12,21 \%$ & $12,48 \%$ & $15,54 \%$ & $13,41 \%$ & $11,98 \%$ \\
\hline
\end{tabular}

\section{Sumber : PT. BPR Batang Kapas}

Berdasarkan tabel 1 diatas dapat dijelaskan bahwa nilai ROA pada PT. BPR Batang Kapas dikatakan baik, karena sudah memenuhi standar PBI No.6/10/PBI/2004 yaitu $0.5 \%$ - $1.5 \%$. Kemudian posisi ROE juga dapat dikatakan bagus pada tahun 2015 hingga 2019 karena telah melewati kisaran PBI No.6/10/PBI/2004 yaitu 5\% - 12.5\%. Sedangkan tingkat NPM berada pada posisi 
yang sangat baik dan telah melampaui kisaran PBI No.6/10/PBI/2004 yaitu 3\% 9.5\%, karena semakin tinggi tingkat NPM menunjukkan kemampuan bank menghasilkan laba semakin efisien.

Berdasarkan perhitungan diatas, maka penulis tertarik melakukan penelitian serta hasilnya dituangkan didalam laporan tugas akhir dengan judul "Analisis Laporan Keuangan Berdasarkan Tingkat Rentabilitas PT. Bank Perkreditan Rakyat (BPR) Batang Kapas".

Adapun perumusan masalah dalam penulisan tugas akhir ini yaitu bagaimana tingkat rentabilitas pada PT. BPR Batang Kapas selama periode 20152019.

\section{LANDASAN TEORI}

Bank merupakan sektor usaha yang bergerak di bidang keuangan yang melakukan kegiatan menghimpun dan menyalurkan dana kepada masyarakat. Menurut Puspitasari (2014) bank yaitu lembaga intermediasi antara pihak yang membutuhkan dana,bank berperan penting saat menggerakkan perekonomian suatu negara dan pembangunan nasional. Menurut Undang-Undang RI Nomor 10 Tahun 1998 Tentang Perubahan Undang-Undang Nomor 7 Tahun (1992) tentang perbankan, bank merupakan sutau badan usaha yang menghimpun dana dari masyarakat dalam bentuk simpanan dan menyalurkannya kembali kebentuk kredit dan bentuk-bentuk lain dalam rangka meningkatkan taraf hidup masyarakat banyak.

Menurut Kasmir (2010) dan Oktavia \& Fernos (2019), Bank-bank disebuah negara bisa dibedakan menjadi beberapa jenis yaitu:

a. Bank sentral

Bank yang berfungsi menjaga keutuhan dan kestabilan nilai rupiah terhadap nilai tukar lainnya seperti emas dan perak.

b. Bank umum

Bank yang kegiatannya menghimpun dana dari masyarakat yang dapat di investasikan dalam bentuk penanaman modal kemudian juga menyalurkan dana yang telah diperoleh dalam bentuk kredit seperti kredit modal kerja, kredit usaha, biaya pendidikan dan lain sebagainya.

c. Bank perkreditan rakyat

Yang melaksanakan kegiatan usaha secara konvensional atau sesuai prinsip islam dimana BPR tidak dapat melakukan kegiatan transaksi giral.

\section{Laporan Keuangan}

Laporan keuangan merupakan laporan yang memberikan gambaran mengenai kondisi keuangan suatu perusahaan pada jangka waktu tertentu atau periode pelaporan. Sedangkan menurut Hanafi (2007) dan Sunreni (2015) laporan keuangan merupakan sebuah alat yang dijadikan acuan penilaian meramalkan kondisi keuangan, operasi dan hasil usaha perusahaan.

Laporan keuangan ialah pencapaian akhir dari proses pencatatan, merupakan suatu ringkasan dari transaksi-transaksi keuangan yang terjadi selama tahun buku bersangkutan. Menurut pernyataan standard akuntansi keuangan (PSAK) yaitu, laporan keuangan merupakan salah satu dari proses pelaporan keuangan. Menurut Amelia \& Afriyeni (2019) dan Munawir (2010) laporan 
keuangan yang lengkap biasanya meliputi laporan posisi keuangan (neraca), laba rugi komprehensif, perubahan laba ditahan, arus kas dan catatan atas laporan keuangan. Laporan keuangan terdiri atas :

a. Neraca

Neraca terdiri dari aktiva, passiva dan modal yang menunjukkan arti bahwa neraca adalah pokok utama dari laporan keuangan. Dimana pada sisi kanan merupakan akun-akun harta atau kekayaan dan sebelah kiri akun-akun liabilitas dan modal.

b. Laporan laba rugi

Laporan laba rugi merupakan gabungan antara pendapatan dan biaya dari suatu perusahaan yang wajib dikeluarkan oleh perusahaan tersebut sesuai dengan periode yang telah ditentukan.

c. Laporan arus kas

Laporan arus kas merupakan suatu laporan yang menggambarkan data informasi dari kas masuk dan kas keluar di perusahaan dan setara kas suatu entitas untuk periode yang telah ditentukan. Serta untuk mengetahui tujuan penggunaan dana yang telah diperoleh suatu perusahaan tersebut.

d. Catatan atas laporan keuangan

\section{Rasio Keuangan}

Rasio keuangan adalah sarana yang digunakan oleh suatu perusahaan untuk menyajikan posisi keuangannya dengan menggunakan berbagai pendekatan rasio. Tujuan pengukuran rasio ini adalah agar laporan yang dihasilkan dapat sesuai dengan standar akuntansi keuangan, lebih akurat, dapat diuji dan dibandingkan.Rasio ini dapat berguna bagi para pengguna laporan keuangan seperti para investor, kreditur, serta pihak manajemen perusahaan itu sendiri.

Menurut Yansi (2015) rasio keuangan dibedakan menjadi beberapa bentuk yaitu :

a. Rasio likuiditas

Rasio yang menggambarkan seberapa besar perusahaan mampu membayar hutangnya untuk

krediturnya atau kewajiban jangka pendeknya.

b. Rasio solvabilitas

Rasio ini bertujuan untuk mengukur kemampuan perusahaan dalam membayar kewajiban jangka panjangnya baik kepada investor ataupun krediturnya.

c. Rasio aktivitas

Rasio aktivitas adalah rasio yang menunjukkan kemampuan perusahaan dalam mengelola penggunaan aktiva secara efesien.

d. Rasio rentabilitas

Rasio rentabilitas adalah rasio yang mengukur tingkat keuntungan yang diperoleh dengan pemanfaatan kekayaan yang dimiliki dibandingkan dengan modal yang tersedia serta total dari setiap penjualan selama periode waktu tertentu. 


\section{e. Rasio investasi}

Rasio ini merupakan menggambarkan tingkat investasi oleh penanam modal dalam bentuk surat berharga terutama yang berada di pasar modal.

\section{Pengertian Rasio Rentabilitas}

Rasio dipergunakan untuk mengukur profit diperoleh dari modal-modal yang digunakan untuk operasi tersebut (rentabilitas) atau mengukur kemampuan perusahaan memperoleh keuntungan (Munawir, 2004).

Rasio rentabilitas bertujuan untuk menilai seberapa efektif manajemen perusahaan dalam mengelola perusahaannya dengan dalam menghasilkan laba dan aktivas perusahaan sebelum pembayaran bunga dan pajak secara efektif maupun efesien. Tinggi rasio ini menunjukkan tingkat efesiensi perusahaan yang semakin baik demikian pula sebaliknya (Rahmadani et al., 2014).

\section{Jenis-Jenis Rasio Rentabilitas}

a. Return On Asset (ROA)

Rasio diperlukan saat menilai kinerja perusahaan menggunakan aktiva untuk mencapai suatu laba pada perusahaan (Sari \& Dewi, 2015). Apabila ROA-nya besar pada suatu perusahaan maka tingkat keuntungan yang diperoleh akan semakin baik pula posisi bank dari segi aset.

Laba sebelum pajak merupakan hasil dari operasional ditambah ataupun dikurangi dengan selisih pendapatan dan biaya-biaya lainnya yang dibutuhkan ketika proses kegiatan produksi bisnis berlangsung.

Return On Asset (ROA) dapat dihitung menggunakan rumus sebagai berikut :

$$
R O A=\frac{\text { Laba sebelum pajak }}{\text { Total aktiva }} X 100 \%
$$

b. Return On Equity (ROE)

Menurut Darsono (2005) dan Afriyeni (2009) ROE merupakan sebuah rasio yang digunakan oleh suatu perusahaan dalam proses mengukur kemampuan dengan menggunakan semua dana yang berasal dari modal sendiri (ekuitas) dalam menghasilkan laba.

Laba bersih setelah pajak ini merupakan selisih dari pendapatan, harga pokok penjualan dan beban dikeluarkan dalam proses menghasilkan pendapatan (Iwan Hermansyah, 2008).

Return On Asset (ROE) dapat dihitung dengan menggunakan rumus sebagai berikut :

$$
R O E=\frac{\text { Laba setelah pajak }}{\text { Modal sendiri }} X 100 \%
$$

c. Net Profit Margin (NPM)

Net Profit Margin (NPM) merupakan sebuah rasio yang dipergunakan untuk mencari tingkat kemampuan bank untuk menghasilkan pendapatan dari kegiatan operasi pokok perusahaan tersebut. Atau merupakan kemampuan dari sebuah perusahaan bank untuk menghasilkan laba dibandingkan dari penjualan yang diterim (Oktavia \& Fernos, 2019).

Net Profit Margin (NPM) dapat dihitung dengan menggunakan rumus sebagai berikut : 


\section{Analisis dan Pembahasan}

$$
N P M=\frac{\text { Laba Bersih Setelah Pajak }}{\text { Total Pendapatan Operasional }} \times 100 \%
$$

Untuk menilai kinerja keuangan suatu bank, analisis keuangan yaitu tolak ukur dari rasio menghubungkan berbagai data keuangan satu dengan lain. Analisis dari berbagai macam rasio memberikan pandangan lebih baik mengenai kondisi suatu bank. Menggunakan alat analisis berupa rasio dapat menjelaskan atau memberikan gambaran tentang posisis keuangan perusahaan terutama apabila angka rasio pembanding digunakan sebagai standar. Bank Indonesia menetapkan standar kinerja keuangan yang tercantum dalam Peraturan Bank Indonesia ( PBI ) No. 6/10/PBI/2004, sebagai berikut tabel 2:

Tabel 2

Standar Rasio Berdasarkan Peraturan Bank Indonesia No. 6/10/PBI/2004

\begin{tabular}{lc}
\hline \multicolumn{1}{c}{ Rasio } & Standar Bank Indonesia \\
\hline Return On Asset ( ROA ) & $0.5 \%-1.25 \%$ \\
Return On Equity ( ROE ) & $5 \%-12.5 \%$ \\
Net Profit Margin ( NPM ) & $3 \%-12.5 \%$ \\
\hline
\end{tabular}

\section{Sumber : Bank Indonesia}

Dari tabel 2 diatas dapat dijelaskan bahwa nilai ROA yang ditetapkan PBI No. 6/10/PBI/2004 yaitu $0.5 \%$ - $1.25 \%$ dengan begitu apabila nilai ROA yang didapat antara $0.5 \%-1.25 \%$ atau melebihi maka dapat dikatakan baik, sedangkan jika berada dibawah PBI maka dikatakan kurang baik dan nilai ROE sebesar 5\% $12.5 \%$ dengan begitu apabila nilai ROA yang didapat antara 5\% $-12.5 \%$ atau melebihi maka dapat dikatakan baik, sedangkan jika berada dibawah PBI maka dikatakan kurang baik. Untuk NPM, PBI menetapkan ketentuan yaitu 3\% - 12.5\% dengan begitu apabila nilai ROA yang didapat antara $3 \%-1.25 \%$ atau melebihi, maka dapat dikatakan baik, sedangkan jika berada dibawah PBI, maka dikatakan kurang baik.

\section{Analisis Terhadap Return On Asset (ROA)}

ROA merupakan rasio ini digunakan untuk mengukur seberapa efesiennya sebuah perusahaan dalam proses mengubah uang yang dipergunakan untuk membeli sebuah asset menjadi laba bersih. Dengan demikian semakin tinggi tingkat ROA dari sebuah bank, maka akan semakin besar pula tingkat laba yang akan didapat oleh sebuah bank yang bersangkutan, apabila semakin besar tingkat keuntungan yang didapat oleh bank tersebut maka semakin bagus bank tersebut dari sisi penggunaan asset(Mirza, 2019).Berdasarkan data perkembangan laba bersih sebelum pajak dan total aktiva PT. BPR Batang Kapas pada tahun 20152019 yang ditunjukan pada tabel 3 dibawah ini sebagai berikut: 
Tabel 3

Perkembangan Laba Bersih Sebelum Pajak dan Total Aktiva

PT. Bank Perkreditan Rakyat Batang Kapas

Tahun 2015-2019

( Dalam Rupiah )

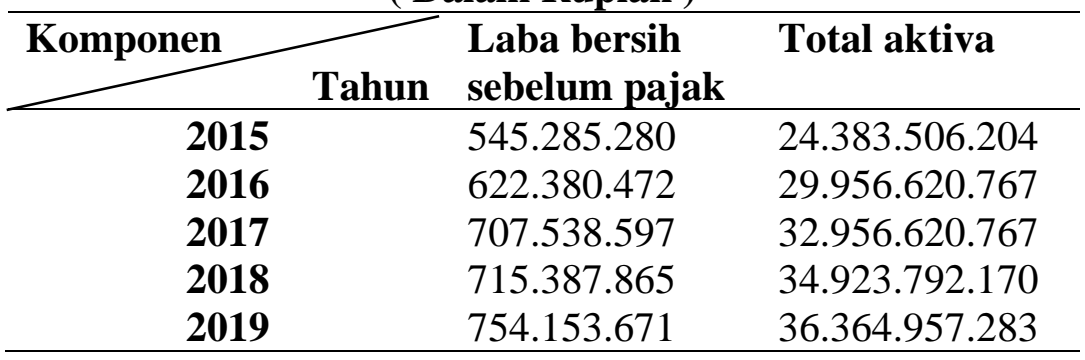

Sumber : PT. BPR Batang Kapas

ROA $=\frac{\text { Laba Sebelum Pajak }}{\text { Total aktiva }} \times 100 \%$

1. Perhitungan ROA tahun 2015

$$
\mathrm{ROA}=\frac{\mathrm{Rp} 545 \cdot 285.280}{24.383 .506 .204} \times 100 \%=2,24 \%
$$

Berdasarkan perhitungan diatas, diperoleh ROA tahun 2015 sebesar 2,24\% dengan begitu bank dapat dikatakan dalam memperoleh labanya sangat baik, karena berada diatas ketentuan yang ditetapkan PBI No.6/10/PBI/2004yaitu berada antara 0,5\% - 1,25\%(tabel 2).

2. ROA tahun 2016

$$
\mathrm{ROA}=\frac{\mathrm{Rp} 622.380 .472}{\mathrm{Rp} \mathrm{29.956.620.767}} \times 100 \%=2,07 \%
$$

Berdasarkan perhitungan diatas, diperoleh ROA tahun 2016 sebesar $2,07 \%$ dengan begitu bank dapat dikatakan sangat baik dalam memperoleh labanya, karena berada diatas ketentuan yang ditetapkan PBI No. 6/10/PBI/2004 yaitu berada antara 0,5\% - 1,25\%(tabel 2).

3. ROA tahun 2017

$$
\mathrm{ROA}=\frac{\mathrm{Rp} \mathrm{707.538.597}}{\mathrm{Rp} \mathrm{32.956.620.767}} \times 100 \%=2,14 \%
$$

Berdasarkan perhitungan diatas, diperoleh ROA tahun 2017 sebesar $2,14 \%$ dengan begitu dapat dikatakan bank sangat baik dalam memperoleh labanya, karena berada diatas ketentuan yang ditetapkan PBI No. 6/10/PBI/2004 yaitu berada antara $0,5 \%$ - 1,25\%(tabel 2).

4. ROA tahun 2018

$$
\mathrm{ROA}=\frac{\mathrm{Rp} 715.387 .865}{\mathrm{Rp} \mathrm{34.923.792.170}} \times 100 \%=2,04 \%
$$

Berdasarkan perhitungan diatas, diperoleh ROA tahun 2018 sebesar $2,04 \%$ dengan begitu dapat dikatakan sangat baik dalam memperoleh labanya, karena berada diatas ketentuan yang ditetapkan PBI No.6/10/PBI/2004 yaitu berada antara 0,5\% - 1,25\% (tabel 2).

5. ROA tahun 2019

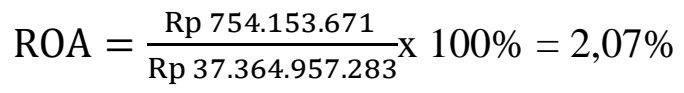

Berdasarkan perhitungan diatas, diperoleh ROA tahun 2019 sebesar $2,07 \%$ dengan begitu dapat dikatakan sangat baik dalam memperoleh 
labanya karena berada diatas ketentuan yang ditetapkan PBI No.6/10/PBI/2004 yaitu berada antara 0.5\% - 1.25\%(tabel 2).

Analisis Terhadap Return On Equity (ROE)

ROE merupakan perbandingan antara laba bersih dengan modal sendiri. Rasio ini merupakan hal yang paling penting oleh calon investor dan pemegang saham untuk menilai kemampuan bank dalam menghasilkan laba bersih yang bersangkutan dengan pembayaran deviden, semakin tinggi rasio ini maka akan semakin baik, karena dapat memberikan tingkat pengembalian yang tinggi terhadap investor.Berdasarkan data perkembangan laba bersih setelah pajak dan modal sendiriPT. BPR Batang Kapas pada tahun 2015-2019 yang ditunjukkan pada tabel 4 dibawah ini:

Tabel 4

Perkembangan Laba Bersih Setelah Pajak dan Modal Sendiri

PT. Bank Perkreditan Rakyat Batang Kapas

Tahun 2015-2019

(Dalam Rupiah)

\begin{tabular}{rll}
\hline Komponen & $\begin{array}{l}\text { Laba bersih setelah } \\
\text { pajak }\end{array}$ & Modal sendiri \\
\hline $\mathbf{2 0 1 5}$ & 504.013 .708 & 2.601 .500 .000 \\
$\mathbf{2 0 1 6}$ & 576.231 .166 & 4.055 .000 .000 \\
$\mathbf{2 0 1 7}$ & 659.699 .437 & 4.055 .000 .000 \\
$\mathbf{2 0 1 8}$ & 670.644 .872 & 4.754 .000 .000 \\
$\mathbf{2 0 1 9}$ & 649.184 .546 & 5.177 .000 .000 \\
\hline
\end{tabular}

Sumber : PT. BPR Batang Kapas

$R O E=\frac{\text { Laba Setelah Pajak }}{\text { Modal Sendiri }} \times 100 \%$

1. ROE Tahun 2015

$$
R O E=\frac{\operatorname{Rp} 504.013 .708}{\operatorname{Rp~} 2.601 .500 .000} \times 100 \%=19,37 \%
$$

Berdasarkan perhitungan diatas, diperoleh ROE tahun 2015 sebesar $19,32 \%$ dengan begitu dapat dikatakan bank sangat baik dalam memperoleh labanya, karena berada diatas ketentuan yang ditetapkan PBI No.6/10/PBI/2004 yaitu berada antara 5\% - 12,5\%(tabel 3).

2. ROE Tahun 2016

$$
R O E=\frac{\operatorname{Rp} 576.231 .166}{\operatorname{Rp~} 4.055 .000 .000} \times 100 \%=14,21 \%
$$

Berdasarkan perhitungan diatas, diperoleh ROE tahun 2016 sebesar $14,21 \%$ dengan begitu dapat dikatakan bank sangat baik dalam memperoleh labanya, karena berada diatas ketentuan yang ditetapkan PBI No.6/10/PBI/2004 yaitu berada antara 5\% - 12,5\%(tabel 3).

3. ROE tahun 2017

$$
R O E=\frac{\operatorname{Rp} 659.699 .437}{\operatorname{Rp} 4.055 .000 .000} \times 100 \%=16,26 \%
$$

Berdasarkan perhitungan diatas, diperoleh ROE tahun 2017 sebesar $16,26 \%$ dengan begitu dapat dikatakan bank sangat baik dalam 
memperoleh labanya, karena berada diatas ketentuan yang ditetapkan PBI No.6/10/PBI/2004 yaitu berada antara 5\% - 12,5\%(tabel 3).

4. ROE Tahun 2018

$$
R O E=\frac{\operatorname{Rp} 670.644 .872}{\operatorname{Rp~} 4.754 .000 .000} \times 100 \%=14,10 \%
$$

Berdasarkan perhitungan diatas, diperoleh ROE tahun 2018 sebesar $14,10 \%$ dengan begitu dapat dikatakan bank sangat baik memperoleh labanya, karena berada diatas ketentuan yang ditetapkan PBI No.6/10/PBI/2004 yaitu berada antara 5\% - 12,5\%(tabel 3).

5. ROE Tahun 2019

$$
R O E=\frac{\operatorname{Rp} 649.184 .546}{\operatorname{Rp} 5.177 .000 .000} \times 100 \%=12,53 \%
$$

Berdasarkan perhitungan diatas, diperoleh ROE tahun 2019 sebesar $12,53 \%$ dengan begitu dapat dikatakan bank sangat baik dalam memperoleh labanya, karena berada diatas ketentuan yang ditetapkan PBI No.6/10/PBI/2004 yaitu berada antara 5\% - 12,5\% (tabel 3.1).

\section{Analisis Terhadap Net Profit Margin ( NPM )}

Rasio ini adalah sebuah perbandingan antara pendapatan dengan laba bersih setelah pajak, semakin besar tingkat NPM, maka kinerja perusahaan dapat semakin produktif. Hal ini dapat berdampak meningkatkan kepercayaan investor untuk menambahkan modalnya pada perusahan tersebut. Berdasarkan data perkembangan laba bersih setelah pajak dan pendapatan operasional PT. BPR Batang Kapas pada tahun 2015-2019 yang ditunjukkan pada tabel 5 dibawah ini:

\section{Tabel 5}

Perkembangan Laba Bersih Setelah Pajak dan Pendapatan Operasional

PT. Bank Perkreditan Rakyat Batang Kapas Tahun 2015-2019

(Dalam Rupiah)

\begin{tabular}{ccccc}
\hline Komponen & $\begin{array}{c}\text { Laba bersih } \\
\text { setelah pajak }\end{array}$ & $\begin{array}{c}\text { Jumlah } \\
\text { pendapatan bunga } \\
\text { lainnya }\end{array}$ & $\begin{array}{c}\text { Pendapatan } \\
\text { operasional } \\
\text { lainnya }\end{array}$ & $\begin{array}{c}\text { Jumlah } \\
\text { pendapatan } \\
\text { operasional }\end{array}$ \\
\hline $\mathbf{2 0 1 5}$ & 504.013 .708 & 4.053 .076 .857 & 74.080 .341 & 4.127 .157 .198 \\
$\mathbf{2 0 1 6}$ & 576.231 .166 & 4.539 .139 .502 & 75.791 .131 & 4.614 .930 .633 \\
$\mathbf{2 0 1 7}$ & 659.699 .437 & 4.717 .778 .700 & 66.137 .270 & 4.243 .915 .970 \\
$\mathbf{2 0 1 8}$ & 670.644 .872 & 4.914 .681 .184 & 84.629 .392 & 4.999 .310 .576 \\
$\mathbf{2 0 1 9}$ & 649.184 .546 & 5.295 .307 .589 & 119.262 .328 & 5.414 .570 .917 \\
\hline
\end{tabular}

Sumber : PT. BPR Batang Kapas

$$
N P M=\frac{\text { Laba Bersih Setelah Pajak }}{\text { Total Pendapatan Operasional }} \times 100 \%
$$

Pendapatan Operasional $=$ jumlah pendapatan Bunga Bersih +

1. NPM 2015 pendapatan Operasional lainnya

$$
N P M=\frac{\operatorname{Rp} 504.013 .708}{\operatorname{Rp~4.127.157.198}} \times 100 \%=12,21 \%
$$

Kemampuan PT. BPR Batang Kapas pada tahun 2015 dalam memperoleh laba bersih jika dilihat dari NPM yang dimilikinya sebesar 
12,21\%. Hal ini menunjukkan bahwa bank sangat efisien dalam menghasilkan laba, karena berada diatas ketentuan yang ditetapkan PBI No.6/10/PBI/2004 yaitu berada antara 3\% - 9,5\% (tabel 4).

2. NPM 2016

$$
N P M=\frac{\operatorname{Rp} 576.231 .166}{\operatorname{Rp~} 4.614 .930 .633} \times 100 \%=12,48 \%
$$

Kemampuan PT. BPR Batang Kapas pada tahun 2016 dalam memperoleh laba bersih jika dilihat dari NPM yang dimilikinya sebesar $12,48 \%$. Hal ini menunjukkan bahwa bank sangat efisien dalam menghasilkan laba, karena berada diatas ketentuan yang ditetapkan PBI No.6/10/PBI/2004 yaitu berada antara 3\% - 9,5\% (tabel 4).

3. NPM 2017

$$
N P M=\frac{\operatorname{Rp} 659.599 .437}{\operatorname{Rp~} 4.243 .915 .970} \times 100 \%=15,54 \%
$$

Kemampuan PT. BPR Batang Kapas pada tahun 2017 dalam memperoleh laba bersih jika dilihat dari NPM yang dimilikinya sebesar $15,54 \%$. Hal ini menunjukkan bahwa bank sangat efisien dalam menghasilkan laba, karena berada diatas ketentuan yang ditetapkan PBI No.6/10/PBI/2004 yaitu berada antara 3\% - 9,5\% (tabel 4).

4. NPM 2018

$$
N P M=\frac{\operatorname{Rp} 670.644 .872}{\operatorname{Rp~} 4.999 .310 .576} \times 100 \%=13,41 \%
$$

Kemampuan PT. BPR Batang Kapas pada tahun 2018 dalam memperoleh laba bersih jika dilihat dari NPM yang dimilikinya sebesar 13,41\%. Hal ini menunjukkan bahwa bank sangat efisien dalam menghasilkan laba, karena berada diatas ketentuan yang ditetapkan PBI No.6/10/PBI/2004 yaitu berada antara 3\% - 9,5\% (tabel 4).

5. NPM 2019

$$
N P M=\frac{\operatorname{Rp} 649.184 .546}{\operatorname{Rp} 5.414 .570 .917} \times 100 \%=11,98 \%
$$

Kemampuan PT. BPR Batang Kapas pada tahun 2019 dalam memperoleh laba bersih jika dilihat dari NPM yang dimilikinya sebesar $12,21 \%$. Hal ini menunjukkan bahwa bank sangat efisien dalam menghasilkan laba, karena berada diatas ketentuan yang ditetapkan PBI No.6/10/PBI/2004 yaitu berada antara 3\% - 9,5\% (tabel 4).

\section{Pembahasan Rasio Rentabilitas}

Berdasarkan analisis yang sudah dilakukan, dapat diketahui bahwa tingkat Return On Asset ( ROA) PT. BPR Batang Kapas tahun 2015 sampai dengan 2019 dapat dikatakan sangat efisien dalam mengelola aktivanya, karena bank mencapai rata-rata yaitu sebesar $2,11 \%$, sedangkan yang ditentukan PBI adalah berada antara $0,5 \%-1,25 \%$.

Pada tingkat Return On Equity (ROE) PT. BPR Batang Kapas pada tahun 2015 sampai dengan 2019 dalam menghasilkan laba setelah pajak memiliki ratarata sebesar 15,29\% sedangkan standar yang ditentukan PBI berada antara 5\% $12,5 \%$, dimana bank dapat dikatakan efesien dalam menghasilkan laba setelah pajak.

Dari Rasio Net Profit Margin (NPM) Pada PT. BPR Batang Kapas pada tahun 2015-2019 tingkat NPM bank ini dapat dikatakan baik, karena bank efisien 
dalam menghasilkan laba dari pendapatan operasional telah mencapai rata-rata sebesar 13,12\% telah memenuhi tingkat ketentuan PBI yaitu berada antara 3\% 9,5\%. Rasio laba bersih ini semakin baik, tapi dalam hal ini belum dapat dijadikan sebagai dasar ukuran yang baik, sebab laba yang diperoleh tersebut juga harus dibandingkan dengan besarnya jumlah dana yang digunakan untuk memperoleh laba tersebut.

\section{SIMPULAN}

Berdasarkan hasil analisis bab sebelumnya, gambaran tingkat rentabilitas PT. BPR Batang Kapas selama periode tahun 2015-2019 dapat disimpulkan bahwa :

1. Return On Asset (ROA) yang dimiliki PT. BPR Batang Kapas untuk tahun 2015-2019 berada pada kondisi sehat atau dapat dikatakan bank telah memperoleh laba dengan baik karena sudah memenuhi ketentuan yang ditetapkan PBI No.6/10/PBI/2004 yaitu berada antara 0,5\% - 1,25\% (tabel 3.1), sedangkan rata-rata dicapai oleh bank sebesar $2,11 \%$.

2. Pada rasio Return On Equity (ROE) pada PT. BPR Batang Kapas untuk periode 2015 hingga 2019 bank mampu menghasilkan laba bersih dengan baik karna telah memenuhi ketentuan yang ditetapkan PBI No.6/10/PBI/2004 (tabel 3.1).

3. Tingkat Net Profit Margin (NPM) PT. BPR Batang Kapas pada tahun 2015-2019 mengalami kenaikan meskipun masih berfluktuasi setiap tahunnya tetapi bank dapat dikatakan baik dalam menghasilkan laba bersihnya.

\section{UCAPAN TERIMAKASIH}

Penulis mengucapkan terima kasih kepada PT. Bank Perkreditan Rakyat (BPR) Batang Kapas telah mengizinkan dan membantu penulis dalam memperoleh informasi. Serta semua pihak yang telah membantu dalam penyelesaian artikel ini.

\section{DAFTAR PUSTAKA}

Afriyeni. (2009). Analisis Pengaruh Pemberian Kredit Terhadap Profitabilitas PT. Bank Pembangunan Daerah (BPD) Sumatera Barat. Kbp, l-No 2, S(2), 95107.

Afriyeni, A., \& Putri, Y. (2019). Analisis Laporan Keuangan Berdasarkan Tingkat Profitabilitas Pada Pt. Bank Perkreditan Rakyat Lpn Tarantang Kabupaten Dharmasraya. Yana Putri, Afriyeni, 1-12. https://doi.org/10.31219/osf.io/rtgxe

Amelia, I., \& Afriyeni, A. (2019). Analisis Kinerja Keuangan Berdasarkan Rasio Solvabilitas Pada Pt. Bpd Sumatera Barat. 1-15. https://doi.org/10.31219/osf.io/tsrzw

Darsono, MBA, A. (2005). Laporan Keuangan (Andi (Ed.)). 
Fernos, J. (2017). Analisis Rasio Profitabilitas Untuk Mengukur Kinerja PT. Bank Pembangunan Daerah Sumatera Barat. Jurnal Pundi, 01(02), 107-118.

Fernos, J., \& Dona, E. (2018). Analisis Loan To Deposit Ratio, Capital Adequacy Ratio dan Return On Assets PT. Bank Pembangunan Daerah Sumatera Barat. Jurnal Pundi, 2(2), 107-118. https://doi.org/10.31575/jp.v2i2.73

Hanafi. (2007). Penerapan Rasio Keuangan Perusahaan (J. Erlangga (Ed.)). Pustaka Quantum IAI.

Harahap, S. S. (1997). Analisis Kritis Atas Laporan Keuangan. PT. Raja Grafindo Persada.

Kasmir. (2010). Analisis Laporan Keuangan (Edisi 1,2,). Rajawali Pers.

Mirza, M., \& Afriyeni, A. (2019). Analisis Rasio Rentabilitas Pada Pt. Bank Pembangunan Daerah (Bpd) Sumatera Barat Cabang Utama Padang. 112. https://doi.org/10.31219/osf.io/5mq98

Munawir. (2004). Analisis Laporan Keuangan (Liberty (Ed.)).

Oktavia, L., \& Fernos, J. (2019). Analisis Laporan Keuangan Berdasarkan Tingkat Rentabilitas Bnk Perkreditan Rakyat (BPR) Batang Palangki. Oktavia, Lastri Fernos, Jhon, 1-12.

Puspitasari, E. (2014). Analisis Faktor-Faktor Yang Mempengaruhi Net Interest Margin Pada Bank-Bank Umum Di Indonesia. Jurnal Ilmu Manajemen, 2(4), 1-13.

Rahmadani, N., Sujana, E., Ari, N., \& Darmawan, N. A. S. (2014). Analisis Pengaruh Rasio Likuiditas, Rasio Profitabilitas, Rasio Rentabilitas Ekonomi dan Rasio Laverage Terhadap Prediksi Financial Distress (Studi Kasus Pada Sektor Perbankan Di Bursa Efek Indonesia Periode 20092013). E-Juornal S1 Ak Universitas Pendidikan Ganesha, 2(1), 1-12.

Sari, D. P., \& Dewi, A. S. (2015). Makanan Dan Minuman Yang Terdaftar Di Bursa Efek Indonesia Periode 2013-2015. 2002.

Sunreni, R. K. dan. (2015). Analisis Laporan Keuangan Untuk Menilai Kinerja Keuangan Pada PT. Nielsen Indonesia Cabang Padang. NASPA Journal, 42(4), 1 .

Undang-undang No. 10 Tahun 1998 tentang perbankan. (1998). 
Undang-undang RI Nomor 10 Tahun 1998 Tentang Perubahan Undang-undang Nomor 7 Tahun 1992. (1998).

Yansi, M. (2015). Manufaktur Sub Sektor Semen Yang Terdaftar. Ekombis Review, 181-186. 